\title{
The effects of debt subsidies on corporate investment behavior: the Korean experience
}

\author{
Mansoor Dailami ${ }^{\mathrm{a}}$ and E. Han Kim ${ }^{\mathrm{b}}$ \\ ${ }^{a}$ World Bank, Washington, DC 20433, USA \\ ${ }^{\mathrm{b}}$ University of Michigan, School of Business Administration, Ann Arbor, MI 48109-1234, USA
}

\begin{abstract}
We argue that credit subsidies are ineffective in stimulating business investment in productive assets. Instead, they will lead to an increase in corporate holdings of financial assets and real estate. For empirical verification we examine corporate investment patterns in Korea between 1984 and 1988. We find a significant positive relation between corporate speculative asset holdings and access to subsidized loans. Our estimates indicate that in the absence of interest rate controls and other forms of subsidies, corporate holdings of speculative assets would have been one-sixth of observed levels. Furthermore, most corporate real estate holdings appear to be unrelated to production activities. In sum, we find little evidence that the Korean government's interest rate controls and credit allocation policy have generated increases in corporate investment; if anything, they are partly to blame for the overheated Korean stock market during the sample period.
\end{abstract}

Key words: Credit subsidies; Investment; Korean economy

JEL classification: E5; G3; O2; O5

\section{Introduction}

Government intervention in the pricing and allocation of credit remains an enduring feature of both developed and developing countries. Although considerable world-wide progress has been achieved in recent years toward financial liberalization and open capital markets, governments continue to deploy credit instruments to address a variety of social, political, and economic problems. In industrialized countries governments frequently intervene on a broad scale in efforts to increase the availability of loans to

\footnotetext{
*Correspondence to: E.H. Kim, University of Michigan, School of Business Administration, Ann Arbor, MI 48109-1234, USA.

The authors are Senior Financial Economist, The World Bank, and Fred M. Taylor Professor of Business Administration and director of Mitsui Life Financial Research Center at The University of Michigan. We would like to thank Bela Balassa, Daniel Ebels, Yoon Shik Park, Rene Stulz, and participants of Economics Seminar at Hitotsubashi University, especially Hidekazu Eguchi and Juro Teranishi for helpful comments and suggestions and Dr. JoongWoong Kim of National Information and Credit Evaluation, Inc. of Korea for providing data. This paper does not reflect the views of The World Bank and its affiliated organizations.
} 
students, farmers, and home owners. ${ }^{1}$ They also extend loan guarantees to exporters and to large cnterprises in financial distress. ${ }^{2}$

In developing countries government intervention figures more prominently. Both loans at subsidized interest rates and government loan guarantees are frequently used to encourage investment and foster industrialization. Governments also impose ceilings on interest rates and loan guarantee fees, provide cheap direct credit to targeted industries, and bail out firms in financial distress.

Two basic assumptions underlie developing countries' reliance on these strategies. First, externalities in financial markets are presumed to follow from either market failure and structural weaknesses and/or from severity of information asymmetries between lenders and borrowers. ${ }^{3}$ Second, it is widcly pcrceived that the various debt subsidies will, by lowering the cost or increasing the supply of funds, induce firms to expand capital holdings in productive assets such as plants and equipment. These investments are in turn anticipated to generate a higher rate of employment and economic growth.

The objective of this paper is to examine the validity of this second assumption. We suggest that access to low cost borrowing may not necessarily lead to higher investment in productive assets, but rather to investment in financial and speculative assets. We elaborate on the conditions under which such an adverse result may occur, and show that these conditions are of a sufficiently general nature to warrant serious attention by policymakers.

For empirical verification we focus on investment patterns in Korea, a country which provides an interesting case study for several reasons. It is well known that Korea has relied on financial market intervention as an important policy instrument for channeling resources to priority sectors and firms. This strategy, which involves directed lending through the Bank of Korea, subsidization of debt via interest rate controls, and provision of loan

${ }^{1}$ For instance, Bosworth et al. (1987), Gale (1990, 1991) and a report by the Congressional Budget Office (1981) describe practices in the United States. For other industrialized countries, see Teranishi (1990), Cox (1986), and the report of The Joint Economic Committee of the U.S. Congress (1981).

${ }^{2}$ The best known examples of federal loan guarantees in the United States are the Lockheed and Chrysler bailouts. See Moritz and Seaman (1981), Ho and Singer (1982), and Chaney and Thakor (1985). Government provisions of loan guarantees abound in other industrialized countries. See, for instance, Green (1985) for the case of France and Sakakibara and Feldman (1983) for Japan.

${ }^{3}$ It is often argued that financial intermediaries, left alone, behave overly conservatively and deny credit to some creditworthy firms with positive net present value projects. The foregoing of such projects entails social welfare costs. This underinvestment problem can be alleviated if government intervention fills the information gap and facilitates the provision of long-term loans to the appropriate users. See Stiglitz (1991) for an in-depth discussion on market failure due to informational asymmetry and moral hazard problems and Berkovitch and Kim (1990) on the interaction between debt contracts and the under- and over-investment incentives. 
guarantees at below market rates, has been a hallmark of Korean industrialization policy since the 1960s. By exercising control over corporate funding, the Government has played an active role in determining allocation of scarce capital. One aspect of this intervention is the provision of funds to priority sectors at preferential rates. A second aspect involves risk sharing in longterm investments. By investing in a project which had the government's blessing, a firm can benefit from the guarantee of a stable and subsidized flow of credit, often irrespective of its economic and financial performance. The result of this policy is a significant reduction in the risk of bankruptcy, which in turn reduces the cost of capital for eligible firms.

How effective has this strategy been? To address this question we proceed in the next section with a discussion of debt subsidies. We then provide a simple theoretical analysis of the effect of debt subsidies on corporate investment behavior. The analysis shows debt subsidies to be ineffective in increasing the stock of productive fixed assets. Instead, subsidies provide an incentive for firms to increase their holdings of speculative assets. Based on these theoretical results we develop a testable hypothesis in Section 3, which is followed by empirical tests in Sections 4 and 5. The results indicate a significant positive relation between the availability of subsidized loans and corporate speculative investment. Section 6 contains concluding remarks.

\section{Corporate debt subsidies and investment behavior}

\subsection{Debı subsidy}

The most obvious form of debt subsidy is the provision of funds at below market interest rates. More subtle implicit subsidies arise when there are: (i) official ceilings on interest rates and loan guarantee fees and (ii) bail-outs of companies in financial distress. Effective ceilings on interest rates and loan guarantee fees create excess demand for credit and lead to rationing. If for some reason (e.g., persuasion by governmental agencies) banks are required to extend or guarantee loans to high risk firms at below-market rates, the firms that are fortunate enough to obtain such loans or guarantees receive an implicit debt subsidy.

To illustrate, consider a bank that must earn a ten percent return on its loans to break even. The bank is contemplating a loan request from a firm that has a five percent probability of default, with twenty percent of the loan recoverable in the event of default. To break even the bank must charge at least $[(1+0.1)-(0.2)(0.05)] /(1-0.05)-1=14.7 \%{ }^{4}$ If this rate exceeds the

\footnotetext{
${ }^{4}$ Let $\widetilde{R}=$ the promised interest rate that fully reflects the default risk of the borrower; $p=$ the probability of default; $d=$ the percentage of the loan recoverable in the event of default; $R=$ the break-even return on the bank's loan portfolio.

Then the promised rate $\widetilde{R}$ that the bank must charge to break even is:
}

$$
\tilde{R}=[(1+R)-p d] /(1-p)-1 \text {. }
$$


interest rate ceiling, the optimal response for the bank is to deny the loan request. Suppose, however, that the bank is required to extend the loan and that the maximum rate it can charge is only 11.5 percent. ${ }^{5}$ At this promised rate, the rate the bank expects to receive is $(1+0.115)(0.95)+(0.2)(0.05)-1=$ $6.925 \%$. Thus, for every dollar loaned, the bank expects to lose $3.075 \%$, which is an implicit subsidy to the borrower.

A ceiling on loan guarantee fees has an identical effect. Suppose the above borrower had instead requested a loan guarantee. Ignoring the costs involved in administering loan guarantees, the minimum guarantee fee that the bank must charge in order to break even is $(1-0.2)(0.05) /(1-0.05)=4.2 \%$ of the amount loaned. ${ }^{6}$ Suppose, however, that the ceiling on the guarantee fee is only $1.5 \%$ and the bank is required to guarantee the loan. ${ }^{7}$ Then for every dollar guaranteed, the bank expects to lose $0.015(1-0.05)-(1-0.2)(0.05)=$ $-2.575 \%$.

In sum, ceilings on interest rates and loan guarantee fees, in combination with the nonprice allocation of credits, provide implicit interest subsidies to high risk firms.

A final category of debt subsidy results from government bailouts of financially troubled firms. These bailouts typically involve a restructuring of the firm's debt in which the government provides new capital at a substantially below-market interest rate. The new capital often takes the form of mandated bank loans. ${ }^{8}$

\subsection{Effects of debt subsidy on corporate investments}

To analyze the impact of these explicit and implicit debt subsidies on corporate investment behavior, we first consider the traditional approach embodied in both the Keynesian and the neoclassical models of investment. These models reduce the multitude of asset categories on a companies' balance-sheet to a single item. $^{9}$ By concentrating on one asset, which is conventionally taken to be 'productive fixed capital,' these models can

\footnotetext{
${ }^{5}$ The $11.5 \%$ used in this example was the actual interest rate ceiling on Korean bank loans during the mid $1980 \mathrm{~s}$, the sample period used for our empirical tests.

${ }^{6}$ Let $g$ be the loan guarantee fee per dollar of borrowing. Then for each dollar guaranteed the bank will earn $\mathrm{g}$ if the firm does not default, and will lose $(1-d)$ if the firm defaults. (Sce the preceding footnote for notational definitions.) Thus to break even, $g$ must satisfy the following equation

$$
g=(1-d) p /(1-p) \text {. }
$$

${ }^{7}$ The $1.5 \%$ in this example was the official ceiling for loan guarantee fees in Korea for several years during the 1980s.

${ }^{8}$ See Kim (1990) for an analysis of the effects of debt subsidies on the financing behavior of Korean corporations and Teranishi (1990) regarding the nature of government bailouts during the industrialization of Japan.

${ }^{9}$ Theoretically, such an aggregation is viable only if all assets on the company balance sheet are perfect substitutes.
} 


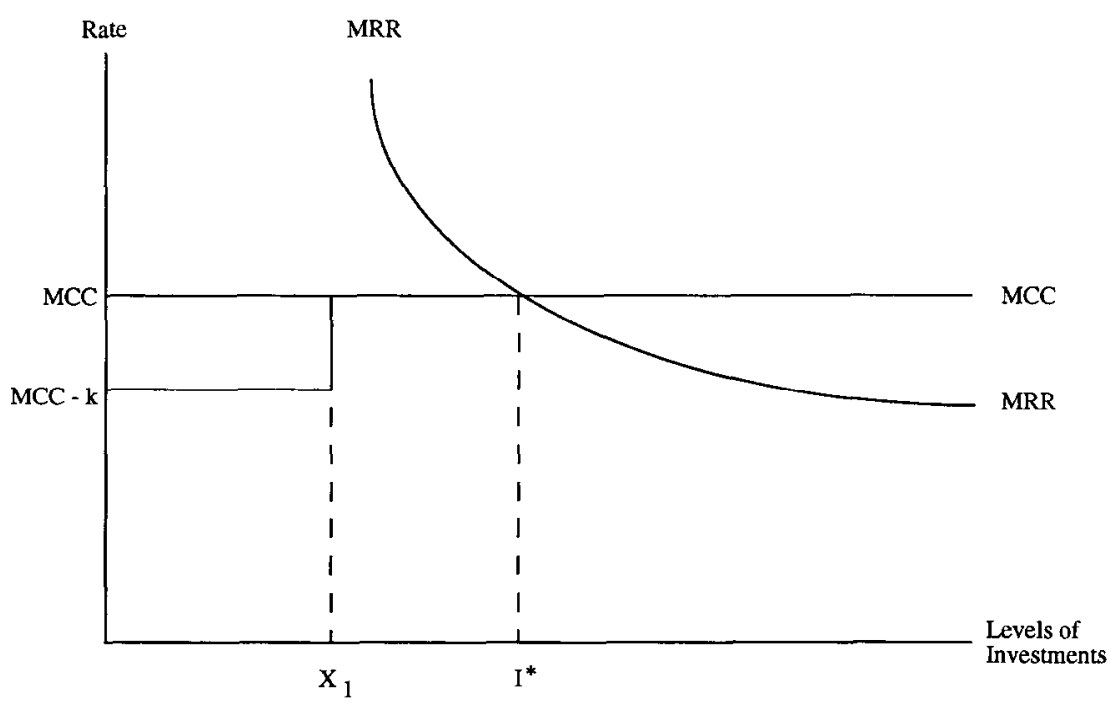

Fig. 1. The impact of subsidized loan $X_{1}$ at MCC- $k$ on corporate investments in productive assets: $X_{1}<I^{*}$.

describe the set of investment opportunities available to the firm by means of a single downward sloping marginal efficiency of capital schedule. Given such a schedule, a lower (marginal) cost of capital brought about, for instance, through interest rate subsidies, is supposed to induce a higher level of investment in productive fixed capital.

This argument is illustrated in Fig. 1 which describes the opportunity set of investments facing a representative firm. Fig. 1 depicts the marginal cost of capital (MCC) line and the marginal rate of return (MRR) curve. The marginal cost of capital should be constant in a competitive capital market. As is typically assumed, the firm is confronted with a decreasing marginal rate of return from incremental fixed investments. Without interest subsidies, the profit-maximizing firm will invest up to $I^{*}$ where the marginal cost of capital is equal to the marginal rate of return.

Suppose, however, that the firm is presented with the opportunity to obtain a subsidized loan in the amount of $X_{1}$ at the rate of MCC minus $k$. The firm's cost of capital will be reduced by $k$ up to $X_{1}$. If $X_{1}$ is less than the profit maximizing level of investment, $I^{*}$, the subsidy does not affect the marginal cost of capital at $I^{*}$ and hence will not increase the investment level. The subsidized loan will only enrich the owners of the firm by an amount $k X_{1}$ without achieving the goal of increasing the firm's investment in fixed assets.

Fig. 2 depicts the case in which the size of the subsidized loan $\left(X_{2}\right)$ is 


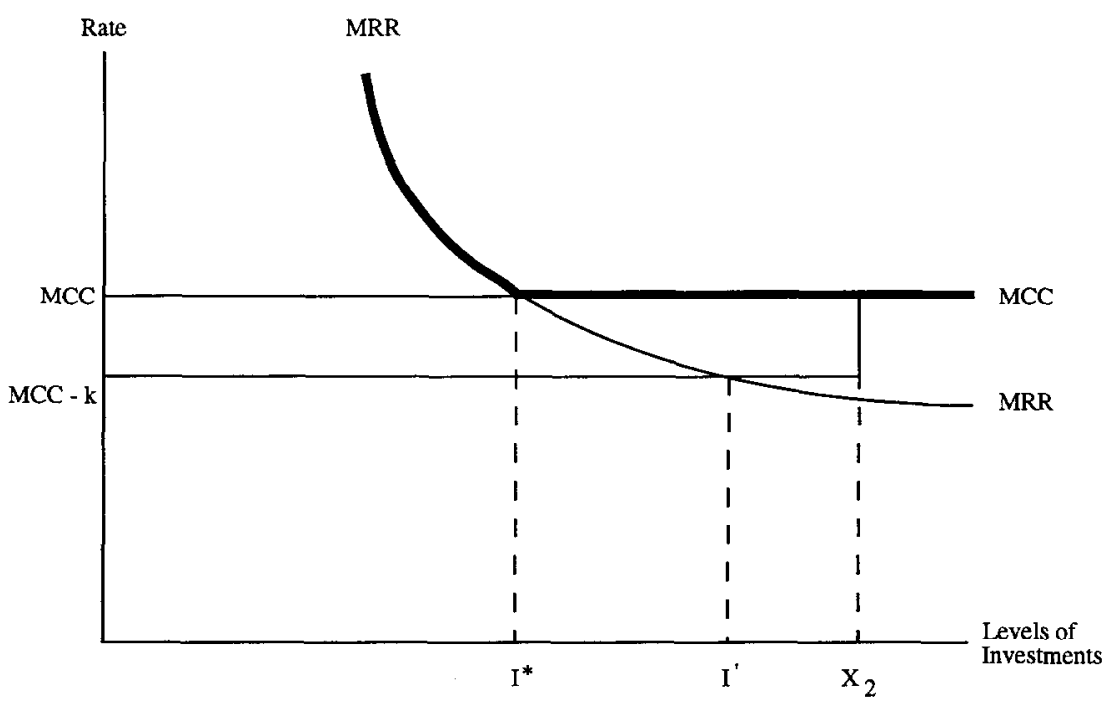

Fig. 2. The impact of subsidized loan $X_{2}$ at MCC- $k$ on corporate investments in productive assets: $X_{2}>I^{*}$.

greater than $I^{*}$. Even in this case, it is unlikely that the firm will increase its investment in fixed assets. Note that the cost of capital is the opportunity cost that the owners of the firm forego by not investing elsewhere. In other words, the marginal cost of capital line not only represents the cost of obtaining funds, but also represents the investment opportunity set available to the owners of the firm via 'speculative' assets such as financial assets and real estate. Consequently, the optimal investment decision requires investment in fixed assets only up to the original $I^{*}$ with the remaining amount of $X_{2}$ diverted to speculative assets. This investment path is traced by the bold line in Fig. 2. As in the previous case, the subsidized loan will only enrich the owners of the firm without increasing the firm's investment in productive assets.

The objective of increasing the level of corporate investment beyond $I^{*}$, say to $X_{2}$ or $I^{\prime}$ in Fig. 2, can only be achieved if there is an effective monitoring mechanism that prohibits firms from investing the subsidized loans in anything other than the fixed productive assets which yield rates of return below the firm's opportunity cost of capital. ${ }^{10}$ This would require that (1) the process of investment is verifiable and (2) there is no collusion between the monitoring agent and the firm.

\footnotetext{
${ }^{10}$ Thus in the absence of externalities or non-market benefits from government directed investments, a successful debt subsidy plan would result in a misallocation of resources and reduce the overall efficiency of capital.
} 
In practice governments monitor investments even if the process of investment is not perfectly verifiable, and penalize firms for diverting funds to other uses. While collusion is possible, monitoring agents would require adequate compensation for the risk of detection. Thus a profit maximizing firm will weigh the expected penalties and the cost of bribery against the difference in yields on productive and speculative assets. Consequently, the greater are the expected penalties and the cost of bribery, the greater will be the proportion of subsidized loans used to finance productive assets. In sum, the impact of debt subsidies on the investment behavior of the recipient firm is dependent on the monitoring effectiveness of the government agency which is providing or mandating the subsidies.

\section{The hypothesis}

\subsection{The model}

The theoretical predictions in the preceding section can be formalized by means of a switching regression model with a stochastic sample separation point. Let us define $Y_{i}$ and $X_{i}$, respectively, as the amount of investment in speculative assets by firm $i$ and the net flow of subsidized loans received by firm $i$ in a given year. Then Figs. 1 and 2 imply that, absent any other sources and uses of funds, $Y_{i}$ will be equal to $X_{i}-I_{i}^{*}$ if $X_{i}>I_{i}^{*}$ and zero otherwise. More generally, the relation between $Y_{i}$ and $X_{i}$ can be stated as follows:

$$
\begin{aligned}
& Y_{i}=\beta_{0}+\beta_{1} X_{i}+u_{1 i}, \quad \text { if } X_{i}>I_{i}^{*} \\
& Y_{i}=\alpha+u_{2 i}, \quad \text { if } X_{i} \leqslant I_{i}^{*}
\end{aligned}
$$

where $\beta_{0}, \beta_{1}$, and $\alpha$ are the estimation parameters. We assume that the error terms $u_{1 i}$ and $u_{2 i}$ satisfy the usual conditions: $E\left(u_{1 i}\right)=E\left(u_{2 i}\right)=0$, and $E\left(u_{1 i}^{2}\right)=$ $E\left(u_{2 i}^{2}\right)=\sigma^{2}$.

Equation (1) implies that the relation between a firm's investment in speculative assets and its access to subsidized loans depends on whether or not the firm's supply of subsidized loans exceeds the optimal level of investment in productive assets. Thus, for firms with $X_{i}>I_{i}^{*}$, a positive fraction, $\beta_{1}$, of the subsidized loan is used to finance speculative investment. In the extreme case in which government monitoring is either nonexistent or totally ineffective, profit maximizing firms will divert all excess financing (i.e., $X_{i}-I_{i}^{*}$ ) into speculative assets.

For the group of firms for which $X_{i} \leqslant I_{i}^{*}$, we postulate that $\beta_{1}=0 .^{11}$ The

\footnotetext{
${ }^{11}$ We assume that firms fully exhaust subsidized loans before taking out non-subsidized loans or issuing equity. This assumption is valid if the costs of issuing equity or non-subsidized debt are non-trivial, or if the expected penalties are positively related to the fraction of subsidized loans diverted to speculative assets. Kim and Lee (1990) document the cost of issuing equity in Korea.
} 
sample separation between the two groups of firms occurs at the point where $X_{i}=I_{i}^{*}$, i.c., the net supply of subsidized loans is equal to the optimal level of investment in productive assets. Note that the location of this sample separation point is not readily observable as it depends on the determinants of optimal investment in productive assets.

The procedure for estimating the switching regression model (1) is well known (see Kiefer, 1980; Maddala, 1983). Let the probability that firm $i$ belongs to the group of firms with net flows of subsidized loan in excess of $I_{i}^{*}$ be:

$$
P_{i t}=\operatorname{Pr}\left[I_{i}^{*}<X_{i}\right]=F\left(Z_{i t} \theta_{t}\right)
$$

where $Z_{i t}$ is a matrix containing observable determinants of each firm's optimal investment in productive assets and supply of subsidized loans, $\theta_{t}$ is a corresponding vector of parameters, and $F(\cdot)$ is the standard normal distribution function. Potential candidates for inclusion in the matrix $Z$ would include the firm's level of output and profits which may be related to the optimal level of investment in productive assets and the firm's access to subsidized loans.

Assume that a proportion $\lambda$ of observations are generated by regime $I$ and $(1-\lambda)$ by regime II, where regime I represents the group of firms for which $X_{i}>I_{i}^{*}$, and regime II represents the remaining firms. Then the likelihood function for an observation $Y_{i}$ can be written as:

$$
L\left(\lambda, \beta_{0}, \beta_{1}, \alpha, \sigma^{2}\right)=\lambda L_{1}\left(\beta_{0}, \beta_{1}, \sigma^{2}\right)+(1-\lambda) L_{2}\left(\alpha, \sigma^{2}\right)
$$

where $L_{1}$ and $L_{2}$ are, respectively, given by

$$
\begin{aligned}
& L_{1}=(2 \pi)^{-1 / 2} \sigma^{-1} \exp \left\{-\frac{1}{2}\left(Y_{i}-\beta_{0}-\beta_{1} X_{i}\right)^{2} / \sigma^{2}\right\} \\
& L_{1}=(2 \pi)^{-1 / 2} \sigma^{-1} \exp \left\{-\frac{1}{2}\left(Y_{i}-\alpha\right)^{2} / \sigma^{2}\right\}
\end{aligned}
$$

Assuming that $u_{1 i}$ and $u_{2 i}$ are normally and independently distributed, the likelihood function for observations $\left(Y_{1} \ldots Y_{N}\right)$ is given by

$$
L\left(\lambda, \beta_{0}, \beta_{1}, \alpha, \sigma^{2}\right)=\prod_{i=1}^{N}\left\{\lambda L_{1 i}\left(\beta_{0}, \beta_{1}, \sigma^{2}\right)+(1-\lambda) L_{2 i}\left(\alpha, \sigma^{2}\right)\right\} .
$$

Maximizing the log of likelihood function (6) with respect to its four relevant arguments, we obtain: 


$$
\begin{aligned}
& \hat{\beta}_{1}=\frac{\sum W_{i} X_{i} Y_{i}-(\bar{W} X)(\bar{W} Y)}{\Sigma W_{i} X_{i}-(\bar{W} X)^{2}} \\
& \hat{\beta}\left\{_{0}=(\bar{W} Y)-\beta_{1} \bar{W} Y\right. \\
& \hat{\alpha}=\frac{\Sigma\left(1-W_{i}\right) Y_{i}}{\Sigma\left(1-W_{i}\right)} \\
& \lambda=\frac{\Sigma W_{i}}{N}
\end{aligned}
$$

where $\left.W_{i}=\lambda L_{1 i} /\left[\lambda L_{1 i}+(1-\lambda) L_{2 i}\right)\right]=p_{i}$ is the conditional probability of regime I given $Y_{i} ;(\bar{W} X)$ and $(\bar{W} Y)$ are, respectively, the weighted average of $x_{i}$ and $y_{i}$.

\subsection{Specification}

The estimation of the switching regression model described above involves specifying, first, the optimal level of productive investment $\left(I^{*}\right)$ and, second, the supply of subsidized loans $(X)$. To estimate the optimal level of investment in productive assets, we rely on the following standard model of corporate investment behavior:

$$
I_{t}=\gamma_{0}+\gamma_{1}\left(\gamma_{2} Q_{t}-K_{t-1}\right)+\gamma_{3} F_{t}+v_{t}
$$

where $I_{t}$ is the change in a firm's capital stock of productive assets between year $t-1$ and $t, \gamma_{0}, \gamma_{1}, \gamma_{2}, \gamma_{3}$ are parameters to be estimated, $Q_{t}$ is the firm's level of output as measured by sales plus the change in inventories of final goods, $K_{t-1}$ is its capital stock of productive assets lagged one year, $F_{t}$ is a financial variable alternatively measured by either the firm's previous year profits or by the first difference in the firm's value as measured by the market capitalization of its equity. Finally, $v_{t}$ is a disturbance term. All variables are scaled by the firm's beginning of year book value of total assets.

Equation (11) combines the conventional accelerator model with the usual intertemporal adjustment specification. It also contains a measure of profitability and stock market performance designed to capture the firm's present and future investment opportunities. ${ }^{12}$

If the supply of subsidized loans to each firm is observable, it is possible to determine the probability, $P_{i t}$, that firm $i$ at time $t$ belongs to regime I. Using equation (11) we obtain:

\footnotetext{
${ }^{12}$ Firm profits are included in the micro investment study of Tybout (1985) for Columbia and Nabi (1989) for Pakistan. The relevance of stock market performance to corporate investment behavior in Korea is discussed in detail in Dailami (1990).
} 


$$
\begin{aligned}
P_{i t} & =\operatorname{Pr}\left[I_{i t}^{*}<X_{i t}\right] \\
& =\operatorname{Pr}\left[v_{i t}<X_{i t}-\gamma_{0}-\gamma_{1}\left(\gamma_{2} Q_{i t}-K_{i t-1}\right)-\gamma_{3} F_{i t}\right] \\
& =\Phi\left[\frac{X_{i t}-\gamma_{0}-\gamma_{1}\left(\gamma_{2} Q_{i t}-K_{i t-1}\right)-\gamma_{3} F_{i t}}{\sigma_{v}}\right],
\end{aligned}
$$

where $\Phi(\cdot)$ represents the unit normal distribution function and $\sigma_{v}$ is the standard deviation of $v$.

The quantity of subsidized loans available to individual firms is not directly observable, because neither the quantity of the subsidies nor the identity of the firms which have received the subsidies is public information. Although the priority industries were the heavy and chemical industries in the 1970s and the electronics industry in the 1980s, not all firms in these industries received equal treatment. Furthermore, the eligibility requirements for individual firms changed over time as the government revised its industrial policy.

We proxy for subsidized loan levels with the sum of short and long term domestic loans plus foreign loans, which we henceforth define as 'loans.' There are two justifications for choosing this proxy. First, most explicit debt subsidies for priority industries and firms have been provided through bank loans which are the major source of short and long term domestic loans. Foreign loans are included because most carry explicit government guarantees.

Second, the implicit debt subsidies due to bailouts and ceilings on interest rates and loan guarantee fees mainly apply to loans emanating from banks and other financial intermediaries. Existing interest rate ceilings do not effectively extend to corporate debt instruments with secondary markets. For instance, the interest rate ceiling on corporate bonds is easily circumvented by selling new bond issues at a discount. Furthermore, government bailouts of firms in financial distress usually require bank participation. The new capital provided in bailouts often takes the form of postponing repayment on old bank debt, extension of new bank loans, and the provision of loan guarantees which allow firms to obtain low cost loans outside of the banking system. $^{13}$

To the extent that some of the loans are not subsidized, our proxy overstates the true amount of subsidized loans. Note, however, that in equilibrium risk adjusted rates of rcturn on speculative assets are the same as the risk adjusted cost of non-subsidized loans; consequently, firms have no

\footnotetext{
${ }^{13}$ This heavy reliance on bank participation in the bailout process is possible because Korean banks had been quasi-government agencies during the sample period, when bank presidents, for example, were appointed by the government.
} 
incentive to take out non-subsidized loans to make speculative investments. Thus the upward bias in our estimate of subsidized loans works against detecting a significant relation between our measure of subsidized loans and speculative asset holdings.

\section{Data and measurements}

\subsection{The sample}

The sample of companies analyzed here represents all non-financial corporations listed on the Korea Stock Exchange from 1983 through 1988. The primary data source is the Pacific-Basin Capital Market (PACAP) Data Base from the University of Rhode Island. The PACAP data is supplemented by the data provided by National Information and Credit Evaluation (NICE) Inc. of Korea. NICE compiles the raw data from which the PACAP data base is constructed and hence provides a more detailed breakdown of balance sheet items than does PACAP.

Due to new listings, delistings, mergers, and bankruptcies, the number of non-financial firms listed on the Korea Stock Exchange varies from a low of 275 in 1983 to a high of 441 in 1988. To estimate the parameters of equations (1) and (11) we require sufficiently detailed balance sheet, income statement, and stock market data for all sample firms throughout the sample period. Thus, to be included in the sample, firms must have been listed on the Korea Stock Exchange throughout the 1983-88 period, thereby limiting our sample to 241 firms. The sample covers 27 industries which account, in aggregate, for 62.7 percent of the total market value of non-financial corporations listed on the Korea Stock Exchange at the end of 1988.

\subsection{Subsidized loans}

As discussed in the previous section, we use the sum of short and long term domestic loans plus foreign loans to proxy for the firm's supply of subsidized loans. The net flow of these loans received by each firm in a given year is estimated by taking first differences of their beginning and end of year outstanding balances. ${ }^{14}$ Table 1 shows that during the 1983-1988 sample period, total domestic and foreign loans account on average for about 35 percent of the book value of firm capital, while debentures account for about 22 percent. The table also illustrates a high degree of variability in the loan

\footnotetext{
${ }^{14}$ See User's Guide of PACAP Database for more precise definitions of short-term loans (BAL 11) and long-term loans (BAL 14). The data on foreign loans are obtained from National Information and Credit Evaluation, Inc. of Korea.
} 
Table 1

Mean debt-to-asset ratios (book value based). For Korean non-financial corporations 1983-1988

\begin{tabular}{lrll}
\hline Industry & $\begin{array}{c}\text { Number of } \\
\text { companies }\end{array}$ & $\begin{array}{l}\text { Loan to } \\
\text { asset ratio } \\
\text { (mean) }\end{array}$ & $\begin{array}{l}\text { Debenture to } \\
\text { asset ratio } \\
\text { (mean) }\end{array}$ \\
\hline Fishing & 2 & 0.291 & 0.172 \\
Mining & 3 & 0.228 & 0.173 \\
Food & 20 & 0.307 & 0.194 \\
Beverage & 9 & 0.259 & 0.209 \\
Textile & 22 & 0.363 & 0.284 \\
Apparel and Leather & 8 & 0.407 & 0.165 \\
Wood and Wood Products & 2 & 0.421 & 0.071 \\
Paper and Paper Products & 10 & 0.478 & 0.216 \\
Chemicals & 22 & 0.289 & 0.267 \\
Rubber and Tire & 6 & 0.489 & 0.176 \\
Pharmaceuticals & 17 & 0.296 & 0.212 \\
Plastics & 3 & 0.408 & 0.246 \\
Nonmetallic Mineral & 12 & 0.287 & 0.293 \\
Iron and Steel & 9 & 0.290 & 0.173 \\
Nonferrous Metal & 4 & 0.285 & 0.183 \\
Fabricated Metal & 4 & 0.337 & 0.158 \\
Machinery & 8 & 0.381 & 0.213 \\
Electronic and Electronical & 20 & 0.405 & 0.259 \\
Motor Vehicles and Equipment & 5 & 0.400 & 0.290 \\
Watch Making & 2 & 0.287 & 0.165 \\
Other Manufacturing & 2 & 0.090 & 0.224 \\
Construction & 29 & 0.460 & 0.141 \\
Wholesale & 15 & 0.362 & 0.144 \\
Retail Trade & 1 & 0.436 & 0.184 \\
Land Transportation & 3 & 0.242 & 0.309 \\
Shipping Air Transportation & 1 & 0.302 & 0.434 \\
Air Transportation & 2 & 0.154 & 0.536 \\
Total & 241 & 0.353 & 0.217 \\
& & &
\end{tabular}

to asset ratio across industries. Firms in 'other manufacturing' have the lowest average loan to asset ratio ( 9 percent) while firms in the rubber tire industry have the highest ( 48.9 percent).

\subsection{Measuring investment in speculative assets}

Determining what portion of a firm's assets are being held for speculative as opposed to productive purposes is difficult. Balance sheet information, even if it were available in greater detail, could not fully resolve the issue. Clearly, investments in certain assets, such as machinery and equipment, can be regarded as productive, while investments in marketable securities can be categorized as speculative. The difficulty resides in the treatment of other balance sheet items, particularly land and buildings, which can satisfy both productive and speculative needs. While firms clearly need land and struc- 
tures to house their machinery and equipment, these assets are at the same time known to be the most popular avenues of speculative investment for Korean corporations.

Thus to define speculative assets, we classify total assets into three broad categories: ${ }^{15}$

(i) Liquid assets $=$

Cash + Accounts and Notes Receivable + Other Current Assets $+a$ portion of Investments and Other Assets,

(ii) Productive Assets $=$ Machinery and Equipment + Inventories + Other Fixed Assets $+h$ (Buildings and Land),

(iii) Speculative Assets $=$ Marketable Securities + Investments $+(1-h)$ (Buildings and Land),

where $h$ is a parameter denoting the proportion of the land and buildings category that can be attributed to productive use. ${ }^{16}$

The parameter $h$ is not, of course, directly observable. To estimate $h$ we postulate a linear relation between a firm's productive use of land and buildings and the level of firm output. This relation is estimated based on pooled time-series cross section data for the sample of 241 companies over the 1983-88 period, resulting in 1,446 estimates of $h .{ }^{17}$ The overall mean and median of these estimates during the sample period are 0.135 and $0.078 .^{18}$

\footnotetext{
${ }^{15}$ See User's Guide for the PACAP Database for the definition of cash (BAL 1), Accounts and Notes Receivable (BAL 3), Other Current Assets (BAL 5), Inventories (BAL 4), Marketable Securities (BAL 2), and Investments and Other Assets (BAL 8). In the PACAP Database, Investments and Other Assets consists of four components: Investments, Other Assets, Other Fixed Assets, and Deferred Assets. We assign Investments to the category of speculative assets, Other Assets and Deferred Assets to liquid assets and Other Fixed Assets to productive assets. PACAP Database does not separate fixed assets into machinery and equipment versus buildings and land. These data are obtained from National Information and Credit Evaluation, Inc. of Korea.

${ }^{16} \mathrm{We}$ classify inventories as productive assets and accounts receivables as liquid assets because inventories are directly linked to outputs whereas accounts receivables are a form of lending which can be converted to cash by factoring. The empirical results are not sensitive to the inclusion of inventories in the production investment category.

${ }^{17}$ Specifically, we estimate the following equation
}

$$
(B L)_{i t}=\delta_{0}+\sum_{j=1}^{26} \delta_{j} D_{i j t}+\eta_{0} Q_{i t}+\left(\sum_{j=1}^{26} \eta_{j} D_{i j t}\right) Q_{i t}+e_{i t}
$$

where $B L=$ value of building and land assets, $Q=$ output, and $D_{j} j=1, \ldots 26$, are industry dummy variables. Note that $\left(\eta_{0}+\eta_{j}\right)$ measurcs the marginal capital (land and building)/output ratio for industry $j$. We choose the industry with the lowest marginal capital/output ratio and denote it by $\eta^{*}$. We then generate estimates for $h$ as $h_{i z}=\left(\eta^{*}\right)\left(Q_{i t} / B L_{i z}\right)$, for $t$ equal to 1983-1988, and $i=1, \ldots, 241$. This estimation procedure assumes that all firms require the same land and building/output ratio at the margin. Our attempt to take account of potential differences across industries was not successful because 12 out of 27 industries have four or less firms (see Table 1).

${ }^{18}$ Out of the 1446 estimates, 34 estimates were greater than 1 and one estimate was negative. We assign a value of $h=1$ for those that were greater than one, and $h=0$ for the negative estimate. 
Table 2

Corporate asset composition: Ratio of productive, liquid, and speculative assets to total assets ${ }^{\mathrm{a}}-1983-1988$

\begin{tabular}{lccc}
\hline & \multicolumn{3}{l}{ Mean asset ratio } \\
\cline { 2 - 4 } & Productive & Liquid & Speculative \\
\hline 1983 & 0.376 & 0.450 & 0.174 \\
& $(0.118)$ & $(0.134)$ & $(0.100)$ \\
1984 & 0.365 & 0.448 & 0.187 \\
& $(0.125)$ & $(0.148)$ & $(0.095)$ \\
1985 & 0.362 & 0.446 & 0.192 \\
& $(0.132)$ & $(0.149)$ & $(0.092)$ \\
1986 & 0.358 & 0.452 & 0.191 \\
& $(0.139)$ & $(0.158)$ & $(0.095)$ \\
1987 & 0.353 & 0.455 & 0.192 \\
& $(0.134)$ & $(0.156)$ & $(0.094)$ \\
1988 & 0.355 & 0.443 & 0.202 \\
& $(0.141)$ & $(0.160)$ & $(0.099)$ \\
$1983-1988$ & 0.362 & 0.449 & 0.190 \\
& $(0.132)$ & $(0.151)$ & $(0.096)$ \\
\hline
\end{tabular}

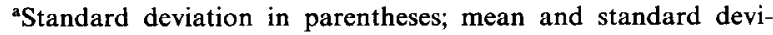
ation are based on the sample of 241 companies.

These results confirm our earlier conjecture that land and buildings are one of the most popular means of speculation for Korean corporations. ${ }^{19}$

Using the above estimates of $h$, Table 2 decomposes total assets into productive, liquid, and speculative assets for each of the years 1983 to 1988. The table reveals little variation in the composition of corporate assets from year to year. On average, firm asset allocation consists of $36.2,44.9$, and 19.0 percent in productive, liquid, and speculative assets, respectively.

The 44.9 percent for liquid assets appears large. One possible explanation is the use of compensating balances to increase the effective lending rate. If the financial institutions were able to attain the market clearing rate via compensating balances, there would be no incentive for firms to take out loans to make speculative investments, which implies that there would be no systematic relation between a firm's investment in speculative assets and the amount of loans outstanding. Thus, we are testing the joint hypotheses that subsidized loans lead to increased speculative holdings and that compensating balances have not completely circumvented the interest rate ceilings. To

\footnotetext{
${ }^{19}$ Although the above estimates may appear at first glance to be extremely low, they are not inconsistent with the prior impression one received from reading Korean daily economic newspapers during the course of this study. Even a casual perusal revealed persistent press criticism regarding excessive real estate holdings by large corporations. Although these criticisms were based on anecdotal evidence, they had led to government policies forcing a massive liquidation of corporate real estate holdings in the early 90's. As of this writing (1990-91), the forced liquidations were still underway.
} 
the extent that compensating balances reduce the interest subsidies, however, our test contains a bias against detecting a positive relation between subsidized loans and speculative asset holdings.

\section{Empirical results}

We report below our estimates of the proportion of speculative assets held by Korean corporations that are attributable to the availability of loan subsidies. Since our theoretical analysis shows that the sample separation point depends on the optimal level of productive investments, we first estimate investment equation (11) utilizing ordinary least squares (OLS) regression methods and pooled time-series cross section data. Our regression model includes a set of yearly and industry dummies. Inclusion of the yearly dummies is designed to capture the effect of macro economic shocks, such as changes in interest rates, inflation, and the foreign exchange rate, while the industry dummies adjust for industry differences.

Table 3 reports the regression results under two alternative specifications for the financial variable: (1) firm profitability lagged one year, and (2) the first difference in the firm's market value of equity. These financial variables are intended to capture the effect of present and anticipated future profitability on decisions to invest in fixed assets.

Several conclusions emerge from the estimates reported in Table 3. First, the estimated coefficients on both output and capital stock are statistically significant and have the expected signs. Furthermore, the magnitude of the coefficients is not sensitive to the choice of financial variables: the coefficients on output and capital stock change respectively from 0.25 to 0.29 and from 0.100 to 0.093 , as we switch from the use of stock market capitalization to previous year's profit.

Second, the estimated coefficient for the financial variable is both positive and statistically significant under either specification. Measuring profitability by the stock market performance results in a higher $R^{2}$. This is not surprising because the stock market based measure is forward looking whereas the previous year's profit is backward looking. The first difference in the firm's market value of equity reflects not only current profitability but also the prospects for future profitability and growth opportunities. Because this variable proves to be both theoretically and empirically superior, we conduct the remaining empirical analyses based on results obtained with the stock market performance measure.

Finally, the estimated coefficients for yearly dummies, with the exception of 1987 in column (1), are all statistically insignificant. This result indicates that the fundamental determinants of corporate investment behavior in Korea were not subject to temporal instability during the sample period.

We use the estimates reported in column (1) of Table 3 to generate 
Table 3

OLS regression coefficients on the determinants of corporate investment in productive assets. (Dependent variable: ratio of investment in productive assets to the beginning of year book value of assets)

\begin{tabular}{lcc}
\hline Independent variables & $(1)$ & $(2)$ \\
\hline Output & 0.247 & 0.292 \\
& $(2.55)$ & $(2.41)$ \\
Capital stock & 0.100 & 0.093 \\
& $(2.92)$ & $(2.68)$ \\
Stock market & 0.243 & - \\
capitalization & $(6.78)$ & \\
Profits & - & 0.166 \\
& & $(3.72)$ \\
Constant & 0.063 & 0.035 \\
& $(2.67)$ & $(1.36)$ \\
Year dummies: & & \\
1985 & 0.002 & 0.001 \\
& $(0.22)$ & $(0.08)$ \\
1986 & -0.011 & -0.005 \\
& $(1.01)$ & $(0.42)$ \\
1987 & -0.025 & 0.001 \\
& $(2.14)$ & $(0.09)$ \\
1988 & -0.018 & 0.006 \\
& $(1.54)$ & $(0.51)$ \\
$R^{2}$ & 0.145 & 0.122 \\
$N$ & 1198 & 1198 \\
Dependent variable mean & 0.0562 & 0.0562 \\
\hline
\end{tabular}

Notes: (1) Sample consists of 241 in 1984, 241 in 1985, 239 in 1986, 238 in 1987, and 239 in 1988, non-financial corporations listed on the Korea stock exchange, covering 27 industries.(2) 26 industry dummies were included in the estimation but are not reported in the table.(3) Absolute values of $t$-statistics are in parentheses.

estimates of $P_{i t}$ in equation (12) and calculate estimates of $\beta_{0}, \beta_{1}, \alpha$, and $\lambda$ as described in equations (7) through (10). The results are reported in Table 4. The estimated value of $\beta_{1}$ is positive and significant, supporting our hypothesis of a positive rclation betwecn the level of speculative investment and access to subsidized loans. The point estimates of $\beta_{1}$ indicate that the proportion of subsidized loans that were diverted to speculative assets ranged from a high of 0.291 in 1987 to a low of 0.06 in 1986. For the 1984-88 period as whole, the average value of $\beta_{1}$ is 0.195 , indicating that about one-fifth of each dollar of subsidized loans is used for speculative purposes.

The proportion of firms receiving subsidized loans in excess of their optimal productive investments, i.e., firms in regime I, declines systematically over time from $53 \%$ of the sample in 1984 to $36 \%$ in 1988 . Thus it appears 
Table 4

Regression coefficients using a switching regression model: Regime $\mathrm{I}: Y_{i}=\beta_{0}+\beta_{1} X_{i}+u_{\mathrm{I} i}$, Regime II: $Y_{i}=\alpha+u_{2 i}$, where $Y_{i}=$ the ratio of investment in speculative assets to the beginning of year book value of total assets for firm $i, X_{i}=$ the ratio of net flow of subsidized loans received to the beginning of year book value of total assets for firm $i, \beta_{i}=$ fraction of subsidized loans used to finance speculative investments. Regime I represents the group of firms for which subsidized loans exceed the optimal level of investment in productive assets, Regime II represents the group of firms for which subsidized loans do not exceed the optimal level of investment in productive assets, and $\lambda$ represents the proportion of observations generated by Regime $I$.

\begin{tabular}{|c|c|c|c|c|c|}
\hline & 1984 & 1985 & 1986 & 1987 & 1988 \\
\hline Subsidized loans $\left(\beta_{1}\right)$ & $\begin{array}{l}0.254 \\
(4.26)\end{array}$ & $\begin{array}{l}0.176 \\
(5.63)\end{array}$ & $\begin{array}{r}0.061 \\
(4.75)\end{array}$ & $\begin{array}{r}0.291 \\
(9.15)\end{array}$ & $\begin{array}{c}0.192 \\
(3.02)\end{array}$ \\
\hline Constant: regime I $\left(\beta_{0}\right)$ & $\begin{array}{l}0.0272 \\
(2.60)\end{array}$ & $\begin{array}{l}0.0220 \\
(2.85)\end{array}$ & $\begin{array}{l}0.0233 \\
(7.00)\end{array}$ & $\begin{array}{l}0.0177 \\
(3.57)\end{array}$ & $\begin{array}{l}0.0442 \\
(4.54)\end{array}$ \\
\hline Constant: Regime II $(\alpha)$ & $\begin{array}{c}0.0502 \\
(11.99)\end{array}$ & $\begin{array}{r}0.0217 \\
(10.33)\end{array}$ & $\begin{array}{l}0.0142 \\
(6.27)\end{array}$ & $\begin{array}{l}0.0278 \\
(8.11)\end{array}$ & $\begin{array}{l}0.0375 \\
(8.46)\end{array}$ \\
\hline $\begin{array}{l}\text { Proportion of firms in } \\
\text { Regime I }(\lambda)\end{array}$ & $\begin{array}{r}0.528 \\
(30.41)\end{array}$ & $\begin{array}{r}0.490 \\
(28.63)\end{array}$ & $\begin{array}{r}0.444 \\
(27.26)\end{array}$ & $\begin{array}{r}0.425 \\
(25.87)\end{array}$ & $\begin{array}{r}0.364 \\
(22.28)\end{array}$ \\
\hline Number of firms & 241 & 240 & 238 & 239 & 241 \\
\hline
\end{tabular}

Absolute values of $t$-statistics are in parentheses.

that there has been a steady improvement in the allocational efficiency of capital.

Table 4 also shows that the constant terms $\beta_{0}$ and $\alpha$ are significantly positive, but the magnitudes are small. The average values of $\beta_{0}$ and $\alpha$ during the $1984-1988$ period are 0.027 and 0.030 , indicating that, on average, firms hold about $3 \%$ of assets in speculative categories irrespective of the availability of subsidized loans. Possible reasons for these investments include the cross holding of shares for control purpose and the temporary investment of excess cash.

Recall that Table 2 shows that on average $19 \%$ of corporate assets are in speculative categories. Comparison of that $19 \%$ with the $3 \%$ for the constant terms in Table 4 indicates that most corporate investment in speculative assets is due to the availability of subsidized loans. Had there been complete financial liberalization such that all interest rates were competitively determined, the fraction of corporate assets invested in speculative assets would have been about one-sixth of observed levels.

To assess the sensitivity of our findings to the estimation method used to separate holdings of buildings and land between productive and speculative purposes, we rerun the switching regression model under two extreme assumptions: (1) all buildings and land were held for speculative purposes, i.e., $h_{i t}=0$, and (2) all were for productive purpose, i.e., $h_{i t}=1$, for all firms over the entire sample period. Table 5 contains the resulting estimates for the coefficients $\beta_{1}$ and $\lambda$. As expected, the estimates of $\beta_{1}$ are much higher under the assumption $h=0$ than under the assumption $h=1$. More interestingly, the 
Table 5

Estimated fraction of subsidized loans used to finance speculative investment $\left(\beta_{1}\right)$ and proportion of observations for which subsidized loans exceed the estimated optimal level of investments in productive assets $(\lambda)$ under two extreme assumptions on the use of buildings and land.

\begin{tabular}{|c|c|c|c|c|c|}
\hline & 1984 & 1985 & 1986 & 1987 & 1988 \\
\hline $\begin{array}{l}\text { Subsidized loans }\left(\beta_{1}\right) \\
\text { (i) all land and buildings } \\
\text { assumed to be speculative } \\
(h=0)\end{array}$ & $\begin{array}{c}0.258 \\
(4.29)\end{array}$ & $\begin{array}{c}0.185 \\
(5.87)\end{array}$ & $\begin{array}{c}0.066 \\
(5.14)\end{array}$ & $\begin{array}{r}0.297 \\
(9.27)\end{array}$ & $\begin{array}{r}0.195 \\
(3.07)\end{array}$ \\
\hline $\begin{array}{l}\text { (ii) all land and buildings } \\
\text { assumed to be productive } \\
(h=1)\end{array}$ & $\begin{array}{r}0.108 \\
(4.51)\end{array}$ & $\begin{array}{r}0.006 \\
(1.00)\end{array}$ & $\begin{array}{c}0.010 \\
(1.43)\end{array}$ & $\begin{array}{c}0.026 \\
(1.86)\end{array}$ & $\begin{array}{r}-0.014 \\
(0.85)\end{array}$ \\
\hline $\begin{array}{l}\text { Proportion of firms in } \\
\text { Regime } I(\lambda) \\
\text { (i)all land and buildings } \\
\text { assumed to be speculative } \\
(h=0)\end{array}$ & $\begin{array}{r}0.532 \\
(30.65)\end{array}$ & $\begin{array}{r}0.493 \\
(28.80)\end{array}$ & $\begin{array}{r}0.445 \\
(27.36)\end{array}$ & $\begin{array}{r}0.429 \\
(26.07)\end{array}$ & $\begin{array}{r}0.367 \\
(22.37)\end{array}$ \\
\hline $\begin{array}{l}\text { (ii) all land and buildings } \\
\text { assumed to be productive } \\
(h=1)\end{array}$ & $\begin{array}{r}0.436 \\
(27.70)\end{array}$ & $\begin{array}{r}0.413 \\
(26.93)\end{array}$ & $\begin{array}{r}0.441 \\
(30.92)\end{array}$ & $\begin{array}{r}0.398 \\
(27.49)\end{array}$ & $\begin{array}{r}0.331 \\
(23.38)\end{array}$ \\
\hline
\end{tabular}

Absolute values of $t$-statistics are in parentheses.

\section{Table 6}

Frequency of negative and positive changes in all other capital excluding subsidized loans (total assets minus subsidized loans) - 1983-1988

\begin{tabular}{llll}
\hline Year & Negative & Positive & Total \\
\hline 1983 & 26 & 215 & 241 \\
1984 & 56 & 185 & 241 \\
1985 & 61 & 180 & 241 \\
1986 & 50 & 191 & 241 \\
1987 & 32 & 209 & 241 \\
1988 & 26 & 215 & 241 \\
\hline
\end{tabular}

assumption $h=0$ increases the estimates of $\beta_{1}$ and $\lambda$ only slightly from those in Table 4. Even under the extreme assumption of $h=1$, the estimates of $\beta_{1}$ remain significantly positive in two out of five years, and the estimates of $\lambda$ continue to be significant throughout the sample period.

The results reported in Tables 4 and 5 assume that subsidized loans must be invested in either productive, liquid, or speculative assets. This need not be so. Subsidized loans can also be used to retire higher cost loans. The end result would be identical to that achieved by the diversion of subsidized loans to speculative assets: the loans would only enrich the borrower without increasing investment in productive assets. To account for this possibility, we treat declines in other liabilities and equity as increases in speculative assets. Table 6 shows that declines in other liabilities and equity occur frequently 
Table 7

Regression coefficients using the switching regresssion model under an alternative definition of speculative assets ${ }^{2}$. Regime I: $Y_{i}=\beta_{0}+\beta_{1} X_{i}+u_{1}$, Regime II: $Y_{i}=\alpha+u_{2 i}$, where $Y_{i}=$ the ratio of investment in speculative assets to the beginning of year book value of total assets for firm $i$, $X_{i}=$ the ratio of net flow of subsidized loans received to the beginning of year book value of total assets for firm $i, \beta_{i}=$ fraction of subsidized loans used to finance speculative investments. Regime I represents the group of firms for which subsidized loans exceed the optimal level of investment in productive assets, Regime II represents the group of firms for which subsidized loans do not exceed the optimal level of investment in productive assets, and $\lambda$ represents the proportion of observations generated by Regime I.

\begin{tabular}{lccccc}
\hline & 1984 & 1985 & 1986 & 1987 & 1988 \\
\hline Subsidized Loans $\left(\beta_{1}\right)$ & 0.327 & 0.204 & 0.066 & 0.251 & 0.167 \\
& $(4.78)$ & $(6.06)$ & $(4.52)$ & $(7.37)$ & $(2.63)$ \\
Constant: Regime I $\left(\beta_{0}\right)$ & 0.042 & 0.041 & 0.041 & 0.033 & 0.055 \\
& $(3.50)$ & $(4.97)$ & $(10.38)$ & $(6.24)$ & $(5.61)$ \\
Constant: Regime II $(\alpha)$ & 0.060 & 0.033 & 0.022 & 0.036 & 0.046 \\
& $(13.93)$ & $(13.03)$ & $(8.53)$ & $(9.95)$ & $(10.27)$ \\
Proportion of Firms & 0.528 & 0.490 & 0.444 & 0.425 & 0.364 \\
in Regime I $(\lambda)$ & $(30.41)$ & $(28.63)$ & $(27.26)$ & $(25.87)$ & $(22.28)$ \\
Number of Firms & 241 & 240 & 238 & 239 & 241 \\
\hline
\end{tabular}

${ }^{a}$ Changes in speculative assets include the decline in other capital, where other capital is defined as total assets minus subsidized loans. Absolute values of $t$-statistics are in parentheses.

and with some yearly variation. Of 241 firms, the number of firms experiencing such declines ranges from 26 in 1983 to 61 in 1985.

Table 7 reports the estimates of $\beta_{1}, \beta_{0}, \alpha$ and $\lambda$ using the revised definition of changes in speculative assets. The results generally approximate those reported in Table 4. However, $\beta_{1}$ is higher in 1984 and 1985 and lower in 1987 and 1988 when compared with our prior estimates. Table 7 reveals a clearer pattern of secular decline in $\beta_{1}$ from a high of 0.327 in 1984 to 0.161 during the 1986-1988 period. Apparently, the proportion of subsidized loans allocated to speculative uses declined by about half after 1986. This declining use of subsidized loans for speculative purposes may be due to the dramatic increase in profitability experienced during the 1986-1988 period. The socalled three lows - low inflation, low oil price, and low exchange rate during the 1986-1988 period reinvigorated the Korean economic miracle. ${ }^{20}$ The increase in profitability due to the three lows may have reduced the incentive to divert subsidized loans to nonproductive uses. ${ }^{21}$

\section{Conclusions}

This paper develops a theoretical model which predicts that, absent

\footnotetext{
${ }^{20}$ The average annual real GNP growth rate was $6.9 \%$ during $1984-1985$ and an astounding $12.1 \%$ during 1986-1988.

${ }^{21}$ Consistent with the above conjecture, new equity offerings increased substantially starting in 1986. See Kim and Lee (1990).
} 
effective government enforcement, subsidized corporate loans will not lead to greater investment in productive assets and will instead be used to finance speculative assets. To test this hypothesis we investigate Korean corporate behavior between 1984 and 1988 .

We find a significant positive relation between corporate investments in speculative assets and access to subsidized loans. About one-fifth of all subsidized loans appear to have been used to finance speculative investments. In addition, over one-third of the sample firms were allocated more subsidized loans than were required for the acquisition of productive assets.

Our estimates indicate that an overwhelming proportion of corporate speculative asset holdings are induced by the availability of subsidized loans. It appears that, had interest rates been competitively determined, the share of corporate assets devoted to speculative holdings would have been one-sixth of that actually observed. Furthermore, a substantial fraction of corporate real estate holdings appears to be unrelated to production activity: our estimates indicate that on average, $86.5 \%$ of all corporate real estate holdings were motivated by speculative purposes. These results imply that corporate investments in speculative assets are excessive and are induced by the availability of subsidized loans. Thus, if the Korean stock market was indeed overheated during the sample period, the government's credit allocation policy and debt subsidies are at least partly to blame. ${ }^{22}$

Finally, what are the implications of our findings for developing economies in general? Did Korea achieve its economic miracle because of, or in spite of, its credit allocation policy? Although analyzing the underlying causes of Korea's economic miracle is beyond the scope of this paper, we believe that Korea's credit allocation policy has been at best a coincidental feature of the Korean success story. Our data reveal a clear pattern of secular decline in the proportion of firms receiving subsidized loans in excess of actual productive investment, from a high of 0.53 in 1984 to 0.36 in 1988. In contrast, the average annual real GNP growth rate increased from $6.9 \%$ during $1984-1985$ to $12.1 \%$ during $1986-1988$.

If anything, the key factors providing the impetus for high economic growth after 1986 were the so-called three lows, low inflation, low oil price, and low exchange rate, which prevailed from 1986 through the end of our sample period. These three lows represent favorable macro shocks that have drastically enhanced the profitability of real investments. The increase in expected profitability in turn has increased the incentives for corporations to invest available funds in productive assets. Our data support this conjecture: the proportion of subsidized loans diverted to speculative investments declined from $27 \%$ during the pre-three-low era (1984-1985) to $16 \%$ during

\footnotetext{
${ }^{22}$ The average rate of return for all stocks listed on the Korean Stock Exchange during the $1984-1988$ period was $56 \%$ per year. See Kim and Lee (1990) for further details.
} 
the three-low era (1986-1988). In conclusion, we find little evidence supporting the contention that subsidized loans have contributed to the corporate investment boom in Korea.

\section{References}

Berkovitch, E. and E.H. Kim, 1990, Financial contracting and leverage induced over- and under-investment incentives, Journal of Finance 45, 765-794.

Bosworth, B.P., A.S. Carron and E.H. Rhyne, 1987, The economics of federal credit programs (The Brookings Institution, Washington, DC).

Chancy, P.K. and A.V. Thakor, 1985, Incentive effects of benevolent intentions: The case of government loan guarantees, Journal of Public Economics 169-189.

Congressional Budget Office, 1981, Conference on the economics of federal credit activity: Part II - papers (Congress of the United States, Washington, DC).

Cox, A., ed., 1985, State, finance and industry: A comparative analysis of post-war trends in six advanced industrial economies (Wheatsheaf Books).

Dailami, M., 1990, Financial policy and corporate investment in imperfect capital markets: The case of Korea, World Bank PRF. Working Papers, No. 409.

Gale, W.G., 1990, Collateral rationing and government intervention in credit markets, in: R.G. Hubbard, ed., Asymmetric information, corporate finance, and investment (The University of Chicago).

Gale, W.G., 1991, Economic effects of federal credil programs, American Econonic Review 81, 133-152.

Green, D., 1985, The state, finance and industry in France, in: A. Cox, ed., State, finance and industry: A comparative analysis of post-war trends in six advanced industrial economies, (Wheatsheaf Books) 80-117.

Ho, T. and R.F. Singer, 1982. Government loan guarantees for the relief of financial distress, in: Paul Wachtel, ed., Crisis in the economic and financial structure (Lexington Books, Lexington, MA) $127-147$.

Joint Economic Committee, The Congress of the United States, 1981, Monetary policy, selective credit policy and industrial policy in France, Britain, West Germany, and Sweden (A staff study), Washington, DC.

Kiefer, 1980, A note on switching regression and logistic distribution, Econometrics 1065-1069.

Kim, E.H., 1990, Financing Korean corporations: Evidence and theory, in: J.K. Kwon, ed., Korea Economic Development (Greenwood Press, London) 341-358.

Kim, E.H. and Y.K. Lee, 1990, Issuing stocks in Korea, in: R. Chang and G. Rhee, eds., PacificBasin capital markets research (North-Holland, Amsterdam) 243-253.

Maddala, G.S., 1983, Limited-dependent and qualitative variables in econometrics (Cambridge University Press).

Mortiz, M., and B. Seaman, 1981, Going for broke: The Chrysler story (Doubleday, New York).

Nabi, I., 1989, Investment in segmented capital markets, The Quarterly Journal of Economics 453-462.

Sakakibara, E. and R.A. Feldman, 1983, The Japanese financial system in comparative perspective, Journal of Comparative Economics 1-24.

Stiglitz, J.E., 1991, Government, financial markets, and economic development, NBER Working Paper No. 3669.

Teranishi, J., 1990, Financial system and the industrialization of Japan: 1900-1970, Banca Nazionale del Lavoro Quarterly Review 310-341.

Tybout, J.R., 1983, Credit rationing and investment behavior in a developing country, Review of Economics and Statistics 598-607.

U.S. Department of Commerce, 1990, Quarterly financial report for manufacturing, minitig, and trade corporations, $1984-1989$. 